\section{SOI: 1.1/TAS DOI: 10.15863/TAS International Scientific Journal Theoretical \& Applied Science}

p-ISSN: 2308-4944 (print) e-ISSN: 2409-0085 (online)

Year: 2017 Issue: 03 Volume: 47

Published: $14.03 .2017 \quad$ http://T-Science.org

SECTION 35. Immovable property. Land relations.

\section{Georgy Mikheev}

Candidate of Economic Sciences, the liveryman of marketing specialists of Russia, the teacher of department of technology, organization, economy of construction and real estate administration,

Kuban state technological university, Russian Federation mgstyle77@yandex.ru

Nikita Semenchenko student 4 rate, profile «Examination and Real Estate Administration», department of technology, organization, economy of a construction and real estate administration, Kuban state technological university, Russian Federation semenchenkonv@gmail.com

\title{
STAGES OF CADASTRAL EXAMINATION IN THE RUSSIAN FEDERATION
}

Abstract: Now the state cadastral registration of the parcels of land represents the main function of the state land cadaster consisting in the description and individualization of the parcels of land in the Unified state register of lands therefore each parcel of land receives such characteristics which allow to allocate unambiguously it from other parcels of land and to perform its high-quality and economic estimates. In article stages of conducting cadastral examination are considered, approaches of conducting the state cadastral registration, and system of the state land cadasters are provided.

Key words: cadastral examination, land cadaster, state cadastral registration.

Language: English

Citation: Mikheev G, Semenchenko N (2017) STAGES OF CADASTRAL EXAMINATION IN THE RUSSIAN FEDERATION. ISJ Theoretical \& Applied Science, 03 (47): 42-45.

Soi: http://s-o-i.org/1.1/TAS-03-47-9 Doi: crosef https://dx.doi.org/10.15863/TAS.2017.03.47.9

\section{Introduction}

Relevance of a subject of a research is caused by value of the state land cadaster as information resource which data are used during the carrying out the state cadastral assessment of lands, transactions with the parcels of land, in case of implementation of the public and municipal authority land resources and for the solution of other tasks. At the same time the state cadastral registration is the main tool of the description of the parcel of land as object of the right and taxation.

In scientific literature it is noted that accounting of lands is a component of the state land cadasters which reflects an economic and natural condition of lands, accumulates and provides the information on their quantity and quality.

The parcel of land is the part of the Earth's surface having accurately designated border, the area, location, legal status and other characteristics considered in the state land cadaster and in the Unified State Register of Rights on real estate and transactions with it $[1$, p. 52; 2, p. 153-1154].

\section{Materials and Methods}

The land code of the Russian Federation among the basic principles of the land legislation called division of lands on purpose on category. Classification of lands is determined proceeding from their belonging to this or that category and the permitted use according to zoning of the territories and requirements of the legislation. In the Russian Federation lands are subdivided into the following categories:

1) earth of agricultural purpose;

2) earth of settlements;

3) the earth of the industry, power, transport, communication, broadcasting, television, informatics, the earth for ensuring space activities, the earth of defense, safety and the earth of other special purpose;

4) the earth of especially protected territories and objects;

5) earth of forest fund;

6) earth of water fund;

7) earth of an inventory.

The order of use and cadastral assessment of lands of settlements are determined according to zoning of their territories, division into territorial zones. In the Russian Federation there are following types of territorial zones in borders of settlements:

- residential;

- public and business; 


\begin{tabular}{l|lrl|l|ll} 
& ISRA (India) & $=\mathbf{1 . 3 4 4}$ & SIS (USA) & $=\mathbf{0 . 9 1 2}$ & ICV (Poland) & $=\mathbf{6 . 6 3 0}$ \\
Impact Factor: & ISI (Dubai, UAE) $=\mathbf{0 . 8 2 9}$ & PUHL (Russia) $=\mathbf{0 . 2 3 4}$ & PIF (India) & $=\mathbf{1 . 9 4 0}$ \\
& GIF (Australia) & $\mathbf{0 . 5 6 4}$ & ESJI (KZ) & $=\mathbf{1 . 0 4 2}$ & IBI (India) & $=\mathbf{4 . 2 6 0}$
\end{tabular}

- production;

- engineering and transport infrastructures;

- recreational;

- agricultural use;

- special purpose;

- water objects;

- other territorial zones.

The land code of the Russian Federation allocates the following types of lands of especially protected territories:

- especially protected natural territories, including medical and improving areas and resorts;

- nature protection appointment;

- recreational appointment;

- historical and cultural appointment;

- other especially valuable lands.

In system of the real estate an object of the economic relations are the parcels of land possessing various consumer properties and the rights to them.

The earth has cost and the adequate land assessment represents one of the most important conditions of normal functioning and development of economy and society. Need for results of an objective land assessment (parcels of land) is felt by both the state, and municipal authorities of the executive authority for the purpose of effective management of land resources and carrying out rational land and tax policy.

Strategic objective of state policy in the sphere of the earth and other real estate - providing conditions for effective use and development of the real estate for the benefit of a requirements satisfaction of society and citizens.

The earth in the Russian Federation as a natural resource, a real estate object and a fixed asset of production is subject to cost assessment. As a result of conducting the state cadastral examination the real picture of cost of lands (parcels of land) in the territory of the Russian Federation will be received that will allow to exercise more effective management of land resources and related real estate objects, and also to carry out the balanced planning of revenues of budgets of all levels (within the payments arriving from the land tax and the rent), to stimulate development of investment processes and development of economy in general.

Need for receipt of reliable estimated value of the parcels of land is felt as the state and municipal authorities of the executive authority in case of management of land resources, implementation of perspective development of settlements, carrying out rational land and tax policy, and private subjects of the land right in case of any making of transactions with the earth, for the purposes of determination of the most rational, most effective development of this or that region, or this or that specific parcel of land.

The description of the parcel of land is made on the system of indicators including: a) The name of the subject of the land right - legal entity or physical person with indication of the exact address, documents certificating the person and financial details. b) Address reference points - the area (the residential massif, the industrial zone), the settlement, the street, house number and structures (in the cities and settlements). c) The documents establishing and certificating the land use right (the resolution, the decision, the order, the state act, the certificate, the lease contract). d) Category of lands, purpose and actual use. e) Code of the qualifier of lands. f) The area according to the documents certificating (establishing) the right to the site, actual including foreign use (depth, width, a form). g) The area of the sanitary protection zone and (or) zone with a specific mode of use within the parcel of land. h) Type of the land right (property - private, state). i) Superficial and subsoil layer, landscape, contour and topography. j) Improvements and engineering arrangement (supply of the electric power, water).

In relation to real estate objects methods of land management solve the following problems: a) development of programs of use and protection of lands on the basis of town-planning, ecological and economic characteristics of the territory [3, p. 27]; b) forming of the parcels of land on single state system and their technical registration; c) project development of creation and streamlining land use with elimination of various inconveniences; d) establishment of borders of the parcels of land, withdrawal of the parcels of land in nature, creation of documents for registration of the rights to the parcels of land; e) fixing and change on the area of line of the cities, settlements and rural settlements; f) carrying out inventory count with identification not used, irrationally used and used not for purpose of lands [4, p. 44]; g) accomplishment of land and estimative works [5, p. 177]. System of a land cadaster, working together with system of the state registration of the rights to the parcels of land and the related improvements, provides: a) owners guarantees of the rights to property; b) system of the taxation - urgent data on the taxation objects; c) the real estate market - open and reliable information about the parcels of land and the related improvements; d) system of bodies of the public and municipal authority - information for forming and carrying out state policy in the sphere of the earth and the real estate, and also planning and development of the territories.

During a transition period to market economy the separate value assessment actually of the parcel of land becomes especially necessary as this methodical approach to assessment of real estate objects allows with rather smaller costs of means and time: a) to promote process of market pricing $[6, \mathrm{p}$. $607 ; 7$, p. 263]; b) to provide return of budgetary funds of municipalities for the improvement performed by them and public improvements in shorter terms $[8$, p. $161 ; 9$, p. 183]; c) to objectively 
assess the actual damage, a lost profit and other compensation payments in cases, stipulated by the legislation [10, p. 22; 11, p. 76-77]; d) to establish concerned parties negotiated prices, including the rent, the amount of mortgage lending.

Enhancement of approaches to conducting the state cadastral registration, and system of the state land cadaster in general, leads to increase in a social and investment potential. The state accounting of the earth as national wealth promotes providing guarantees of the rights to the parcels of land, development of system of the taxation of the earth and other real estate. The questions connected with implementation of functions of the state land cadaster are included in the sphere of the land legislation.

\section{Conclusion}

Activities for conducting the state cadastral registration have a public focus owing to value of a land cadaster as the state information resource concentrating data on all parcels of land in the territory of the Russian Federation. The state cadastral registration, first, is aimed at information support of functions of the public and municipal authority by land resources, including the payments for the earth, fiscal on collection, which are traditionally determining value of land and cadastral activities. In this respect the individualizing signs of the parcel of land shall allow to establish it, first of all, as the taxation object, therefore to admit the fact of existence of the parcel of land regardless of extent of identification of its borders of a pas of the area. Besides, the parcel of land for the purposes of maintaining the state land cadaster is determined not only as a part of the limited Earth's surface, on and as all that is over and under this surface if other doesn't follow from federal laws. The last provides reference to characteristics of the parcel of land availability firmly of the related real estate units that in turn, is caused by the principle of unity of destiny of the parcels of land and firmly related objects. Secondly, by means of the state cadastral registration of the parcels of land it is information the system of the state registration of the rights to real estate and transactions with it, and equally in other state information resources containing data on the parcels of land is provided. The efficiency of land turnover which is a basis for successful development of the land market depends on the timely, reliable and complete cadastral information on the parcels of land and dynamics of their changes. In this aspect the state land cadasters acts as a source and system of fixed storage of such data.

\section{References:}

1. Inkin I, Lapin A, Mikheev G (2016) Origin of economic crime // International scientific review. - 2016. - № 10 (20). - p. 52-53.

2. Mamychev AY, Sulimova EA, Yakovenko NV, Savvidi S, Molchan AS, Dianova VA (2016) Economic security and organizational coulture: theoretical approaches and categorical relationship // International Review of Management and Marketing. 2016. T. 6. № S1. p. 153-158.

3. Molchan AS, Kochian GA, Shadrina JA (2015) Transformation of threats of an economic safety in the food sphere / The International Scientific and Practical Congress of Economists and Jurists "THE GLOBAL SYSTEMIC CRISIS: NEW MILESTONE IN DEVELOPMENT OR AN IMPASSE?" ISAE "Consilium". Davos, Switzerland, 2015. p. 153-157.

4. Frantsisko O, Molchan A, Frantsisko P (2015) Institutional reforms in the agro-industrial complex of russia: genesis, issues, current state // Modern European Researches. 2015. № 3. p. 44-49.
5. Mamedov O, Gvarliani T, Khasheva Z, Zenchenko S, Tatuev A, Molchan A, Klochko E, Kuzmenko V, Kuyantsev I, Tumanyan Y, Trysyachny V, Dikinov A (2014) ECONOMY OF THE NORTH CAUCASUS: PROBLEMS, DIAGNOSIS, PROSPECTS.collective monograph / Oktai Mamedov (Editor). Berlin, 2014. Том 1 Russian Economists on the Russian Economy. p. 218.

6. Dikinov AH (2015) Asymmetries of the North Caucasus federal district subjects' social ecological economic development under macroeconomic tendencies // Biosciences Biotechnology Research Asia. 2015. T. 12. №1. p. 605-608.

7. MindlinYB, Zhukov BM, ProkhorovaVV, Shutilov FV, Belova EO (2016) Main stages of the formation of an economic cluster // International Journal of Economics and Financial Issues. 2016. T. 6. № S1. p. 261-265.

8. Prokhorova VV, Klochko EN, Kolomyts ON, Gladilin AV (2016) Prospects of the agro industrial complex development: economic diversification, business development, mono - 


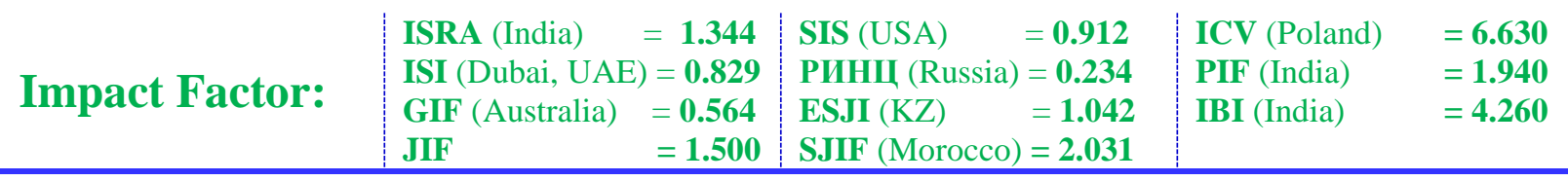

industry town strengthening and expansion // International Review of Management and Marketing. - 2016. - T. 6. - № S6. - p. 159 164.

9. Basyuk AS, Prokhorova VV, Kolomyts ON, Shutilov FV, Anisimov AY (2016) Administration management in the innovation cluster // International Review of Management and Marketing. - 2016. - T. 6. - № 6. - p. 180 184.

10. Filippova MK, Mindlin YB, Litvinenko IL, Kucherov AV, Shichiyakh RA, Prokhorova VV
(2016) Rationale for the Use of the Cluster Approach to the Formation of Localities in the Regional Economic System. International Review of Management and Marketing. 2016, v. 6, no. S1, p. 20-26. 2.

11. Litvinenko IL, Kulikova NN, Kolomyts ON, Gurieva LK, Kamberdiyeva SS (2016) Features of Formation and Development of Innovation Centers Generate. International Journal of Economics and Financial Issues. 2016, v. 6, no. S1, p. 74-80. 